\title{
Analisis Docking Molekuler Senyawa Derivat Phthalimide sebagai Inhibitor Non-Nukleosida HIV-1 Reverse Transcriptase
}

\section{Molecular Docking Analysis of Derivate Phthalimide Compounds as Non-Nucleosida HIV-1 Reverse Transcriptase Inhibitor}

\author{
Tiara Ajeng Listyani ${ }^{1}$, Rina Herowati ${ }^{1}$, Asmiyenti Djaliasrin Djalil ${ }^{2}$ \\ 1) Fakultas Farmasi, Universitas Setia Budi Surakarta, Jawa Tengah. \\ 2) Fakultas Farmasi, Universitas Muhammadiyah Purwokerto, Jawa Tengah. \\ email: tiara.070790@gmail.com
}

\begin{abstract}
Abstrak
Senyawa derivat phthalimide dilaporkan sebagai kelas baru inhibitor nonnukleosida reverse transcriptase. Analisis docking molekuler senyawa derivat phthalimide terhadap enzim reverse transcriptase diperlukan untuk mengetahui afinitas dan pola interaksi antara senyawa di atas dengan enzim reverse transcriptase.

Senyawa derivat phthalimide dioptimasi geometri menggunakan perangkat lunak VegaZZ selanjutnya dilakukan dengan cara preparasi target, preparasi ligan, validasi metode docking, dan analisis docking menggunakan PyRx-Python 0.8 - AutoDock Vina sehingga didapatkan interaksi ligan dengan target, energi bebas pengikatan, ikatan hidrogen, dan pola interaksi. Pola interaksi dilihat dari tiga puluh tiga senyawa derivat phthalimide dengan enzim reverse transcriptase menunjukkan ikatan hidrogen dengan asam amino Lys 101 dimana interaksi tersebut mirip dengan interaksi senyawa TIBO R 86183 yang merupakan ligan asli protein target.
\end{abstract}

Kata kunci : Phthalimide, HIV, Docking, AutoDock Vina

\begin{abstract}
Phthalimide derivate compounds was reported as a new class of nonnucleoside reverse tranckriptase inhibitors. Docking molekuler analysis in phthalimide derivative compounds against reverse transcriptase enzym necessary to determine the affinity and interaction patterns between the above compounds with reverse transcriptase enzym.

Derived compounds phthalimide geometry optimized using VegaZZ software then performed by way of target preparation, ligand preparation, docking method validation, and analysis of docking using PyRx-Python0.8 - AutoDock vina so we get to the target ligand interactions, free energy bonding, hydrogen bonding, and interaction patterns. Interaction pattern seen in thirty-three phthalimide derivatives with reverse transcriptase enzym showed hydrogen bonding with amino acids Lys101 where the interaction is similar to the interaction of TIBO $R$ 86183 compounds which are the original ligands of the target protein.
\end{abstract}

Keywords: Phthalimide, HIV, Docking, AutoDock Vina

\section{PENDAHULUAN}

Acquired Immunodeficiency Syndrome (AIDS) adalah penyakit yang disebabkan oleh virus HIV (human immunodeficiency virus) tipe I. Setelah bergabung dengan sebuah sel, virus HIV menaburkan bahan-bahan genetiknya ke dalam sel. Di sini HIV mengalami masalah dengan kode genetiknya yang tertulis dalam bentuk yang disebut RNA, sedangkan pada manusia kode genetik tertulis dalam DNA. Untuk mengatasi masalah ini, HIV membuat enzim reverse transcriptase yang menyalin RNA-nya ke dalam DNA (Braz, 2010).

$$
\text { Antiretroviral (ARV) bisa }
$$

diberikan pada pasien untuk 
menghentikan aktivitas virus, memulihkan sistem imun, dan mengurangi terjadinya infeksi oportunistik dan menurunkan kecacatan. Salah satu golongan obat ARV adalah inhibitor nonnukleosida reverse transcriptase. Adanya faktor resistensi dan efek samping berupa ruam dan lesi pada penggunaan obatobat ARV yang telah beredar di pasaran membuat para peneliti mencari alternatif senyawa lain yang dapat digunakan untuk pengobatan.

Pada tahun 2004, Samee et al. melakukan penelitian terhadap senyawa derivat phthalimide sebagai kelas baru inhibitor nonnukleosida reverse transcriptase. Derivat phthalimide yang sudah disintesis dan diuji aktivitas penghambatannya secara in vitro, kemudian dilakukan uji 3D QSAR menggunakan metode CoMFA dan CoMSIA. Prediksi dan aktivitas penghambatan eksperimental senyawa derivat phthalimide dengan enzim HIV1 reverse transcriptase pada penelitian tersebut berkorelasi dengan baik dan analisis peta kontur 3D dari kedua model CoMFA dan CoMSIA menawarkan wawasan struktural penting dalam merancang senyawa baru dan lebih aktif.

Phthalimide memiliki sebuah fitur struktural -CO-N-(R)-CO- dan cincin imida yang membuat mereka aktif secara biologis dan sangat berguna di dalam bidang farmasi. Phthalimide bersifat lipofilik dan netral sehingga dapat dengan mudah menyeberangi membran biologis in vivo dan menunjukkan aktivitas farmakologi yang berbeda. Diperlukan pengembangan lebih lanjut untuk merancang senyawa phthalimide yang lebih poten dalam menghambat HIV-1 reverse transcriptase. Kemajuan teknik-teknik komputasi yang ada saat ini memungkinkan dilakukannya uji-uji in silico untuk mempercepat proses pemilihan senyawa-senyawa yang akan disintesis melalui identifikasi dan optimasi senyawa-senyawa penuntun di dalam proses penemuan obat (Computer Aided Drug Design/CADD) (Talele et al. 2010).

Penelitian ini bertujuan untuk mengidentifikasi senyawa derivat phthalimide sebagai inhibitor nonnukleosida reverse transcriptase dilihat dari energy binding hasil perhitungan secara in silico menggunakan aplikasi Autodock Vina dalam software PyRx. Metode ini berguna untuk memberikan pengetahuan awal tentang jenis ikatan senyawa obat sebagai ligan dengan makromolekul tertentu sehingga dapat menentukan senyawa yang lebih potensial sebagai penghambat HIV-1 reverse transcriptase tanpa mengakibatkan efek biologis yang merugikan dan berpeluang untuk digunakan sebagai sediaan oral. Hasil penelitian ini diharapkan dapat digunakan sebagai dasar untuk melakukan penelitian eksperimental selanjutnya.

\section{METODE PENELITIAN}

\section{Bahan}

Struktur tiga dimensi HIV-1 reverse transcriptase yang diunduh dari Protein Data Bank (RCSB PDB) dengan identitas 1HNV (Ding 1995) yang berasal dari organisme Escherichia coli. Desain struktur tiga dimensi ligan uji 
yaitu 33 senyawa derivat phthalimide menggunakan ChemOffice2004 beserta data aktivitas penghambatannya terhadap HIV-1 reverse transcriptase (Samee et al. 2004). Struktur senyawa nevirapine yang merupakan obat ARV yang sudah beredar di pasaran dan struktur senyawa TIBO R86183 yang merupakan ligan asli dari makromolekul target sebagai kontrol positif (Ding 1995). Struktur senyawa parasetamol yang dapat dilihat pada (https://pubchem.ncbi.nlm.nih.gov/)

sebagai kontrol negatif.

Alat

Hardware

Komputer notebook Asus model X540Y (spesifikasi: Processor AMD E17010 Dual-core 1.5Ghz, RAM 2 Giga Byte, Hard disk 500 Giga Byte, Kartu Grafis AMD Radeon R2)

Software

Windows 7 Ultimate, ChemDraw Ultra 8.0, Chem3D Ultra 8.0, Discovery Studio Visualizer v17.2.0.16349, VegaZZ 3.1.1.42, PyMOL 1.3, PyRxPython 0.8 - AutoDock Vina.

\section{Uji docking molekuler}

Pengunduhan makromolekul HIV-1 reverse transcriptase

Makromolekul HIV-1 reverse transcriptase diunduh dari Protein Data Bank (RCSB PDB) dengan identitas 1HNV (Ding 1995) dalam format .pdb

\section{Pembuatan struktur tiga dimensi ligan uji.}

Struktur dua dimensi 33 senyawa ligan uji di buat menggunakan aplikasi ChemDraw Ultra 8.0, kemudian di konversi ke model 3D dengan Chem3D Ultra 8.0 dengan cara klik edit, klik get
3D model, setelah itu struktur 3D disimpan dengan format PDB file. Struktur tiga dimensi kemudian di optimasi menggunakan VegaZZ (Freeware) dengan langkah calculate, pilih ammp, klik minimization, kemudian disimpan klik save as (nama ligan) format.pdb untuk uji docking.

Tabel 1 Aktivitas penghambatan senyawa derivat phthalimide terhadap enzim reverse transcriptase secara in vitro (Samee et al. 2004).

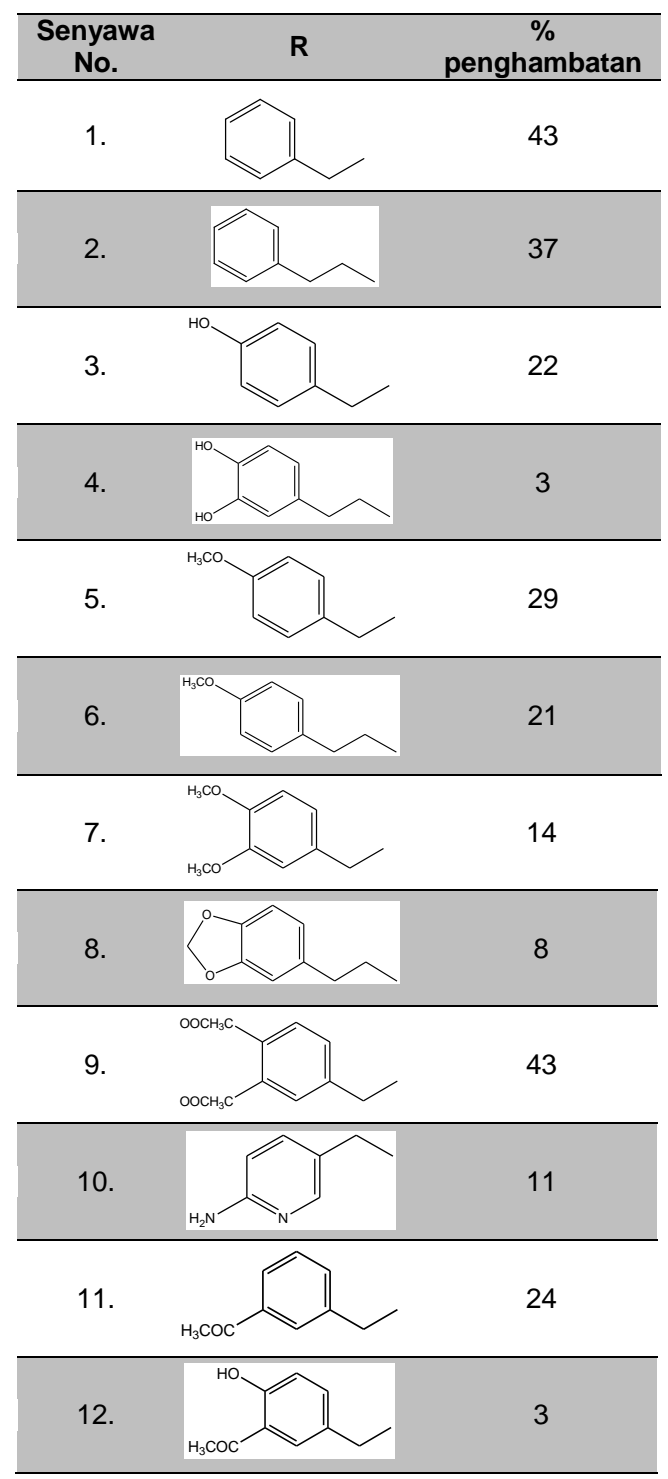




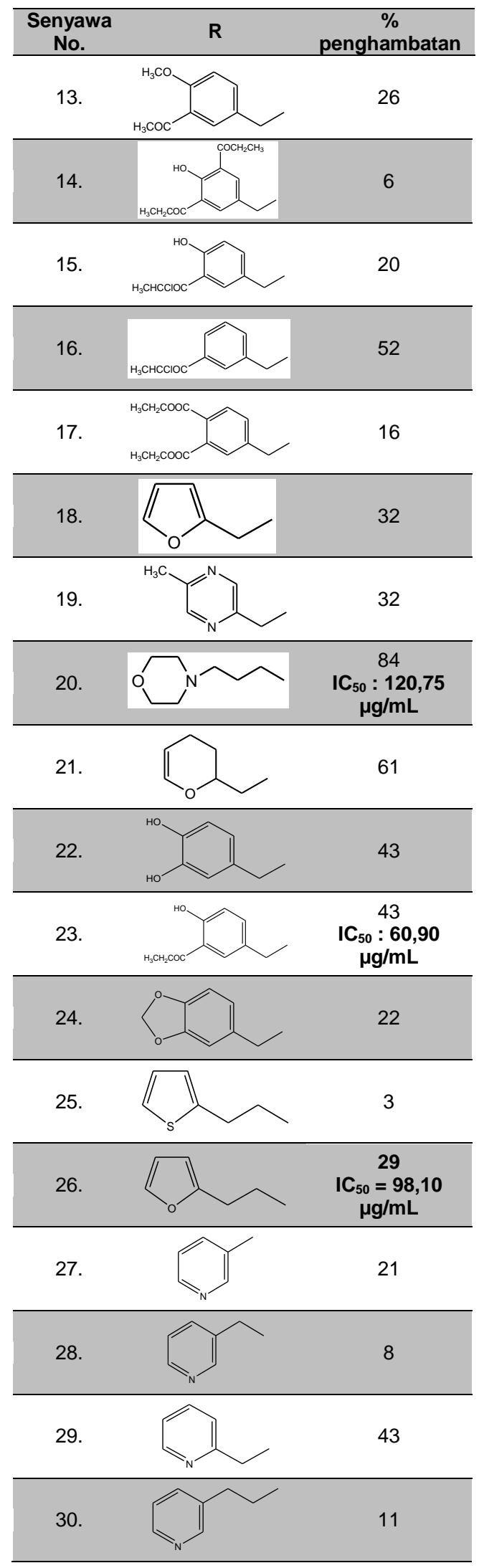

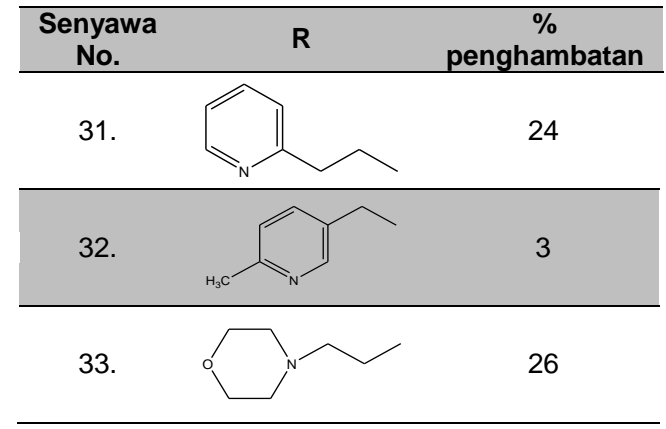

\section{Pemisahan rantai makromolekul.}

Pemisahan struktur makromolekul dengan ligan menggunakan aplikasi Discovery Studio Visualizer, dengan langkah; open icon Discovery Studio Visualizer, klik file kemudian open, cari folder tempat file makromolekul yang ingin dipisahkan, kemudian akan muncul tampilan tiga dimensi struktur protein target. Rantai molekul, ligan dan residu yang tidak diperlukan dihilangkan dengan langkah; klik script $\rightarrow$ selection select water molecules / ligand / protein chains $\rightarrow$ edit $\rightarrow$ delete. File makromolekul yang sudah siap kemudian disimpan dalam format.pdb.

\section{Optimasi geometri struktur senyawa} uji

Struktur dua dimensi senyawasenyawa yang akan ditambatkan dibuka melalui program VegaZZ dan ditampilkan dalam bentuk tiga dimensinya lalu ditambahkan atom hidrogen. Senyawa diperbaiki muatannya dengan menambahkan muatan parsial gasteiger charges lalu diberi forcefield autodock. Senyawa diminimisasi sebanyak 3000 langkah untuk memperoleh konformasi yang paling stabil. Optimasi dilakukan untuk menghasilkan energi molekul terendah. Selanjutnya masing-masing senyawa 
yang telah dioptimasi disimpan dalam format .mol.

\section{Proses docking molekuler}

Proses docking molekuler menggunakan PyRx 0.8 yang menggunakan sistem Autodock Vina, AutoDock 4.0(AD4.0) dan AutoDock Tools (ADT). Struktur makromolekul dan ligan yang telah dioptimasi secara terpisah disimpan dalam satu folder yang sama. Untuk docking molekuler menggunakan Pyrx 0.8 terlebih dahulu dengan tahapan sebagai berikut: dibuka aplikasi PyRx 0.8 kemudian load molecule pada folder tempat menyimpan. Setelah file semua tersedia kemudian di klik kanan pilih AutoDock pilih ligand (untuk ligan yang akan diuji) dan macromolecule untuk protein yang diuji. Di bagian Vina Wizard klik start here kemudian pilih local (apabila belum tertandai) kemudian start. Pada tampilan select molecules, dipastikan ligan dan macromolecule selected, sebab ketika ligan dan makromolekul belum dipilih maka akan berakibat langkah selanjutnya tidak dapat diforward. Apabila belum dipilih bagian add ligan atau add molecule dapat dipilih atau pada bagian AutoDock dapat di blok bagian ligan yang ingin diuji ataupun bagian makromolekul kemudian diforward ke run vina. Di bagian selanjutnya terdapat gridbox yang dapat diatur pada tabel view, di arahkan pada binding site sebagai titik tengah, kemudian dicatat koordinat $\mathrm{x}, \mathrm{y}$ dan z. Kemudian diklik run vina, maka proses docking akan dimulai dan tunggu hingga $100 \%$ maka hasil akan muncul pada tabel analyze result. Klik ligand out dengan binding affinity terkecil kemudian pada tabel navigator akan klik molecule pilih ligand out yang telah diklik di tabel analyze result, kemudian klik kanan save as PDB.

Validasi metode docking terhadap ligan natif dilakukan untuk mencari konformasi 3D ligan natif terhadap reseptor dengan memperhatikan koordinat pusat masa struktur dan besaran gridbox dari binding site pocket dalam satuan angstrom (Vina) atau number of points (AutoDock). Konformasi hasil docking yang diperoleh disejajarkan dengan konformasi ligan natif hasil pengukuran kristalografi yang dinyatakan dalam nilai root mean square deviation (RMSD). Hasil penelitian sebelumnya, nilai RMSD untuk kesejajaran konformasi struktur yang masih dapat diterima adalah kurang dari 5 , semakin mendekati nilai 0 maka nilai kesejajaran semakin baik. (Saputri et al. 2016)

Docking molekular dan analisis data docking ligan uji dilakukan untuk menghasilkan nilai binding energy dalam satuan $\mathrm{kkal} / \mathrm{mol}$. Nilai binding energy yang digunakan adalah yang memperoleh nilai semakin minus, apabila terdapat nilai minus maka kekuatan ikatan dapat dipastikan terjadi. Masing masing data yang diujikan diambil 2 data terbaik. Data ligan uji yang sudah dikumpulkan dibandingkan dengan ligan natif. Data interaksi ligan protein ditampilkan dengan menggunakan PyMOL dan Discovery Studio Visualizer untuk melihat residu asam-asam amino yang terlibat dan ikatan yang terjadi antara senyawa yang diteliti dengan target protein. Ikatan yang terjadi terutama pada sisi aktif yaitu pada asam amino yang sesuai akan dijadikan prediksi sementara serta 
kemampuan senyawa derivat phthalimide yang tertambat pada molekul protein sasaran yang terbesar akan dijadikan sebagai dasar penentuan senyawa dengan aktivitas terbaik.

\section{HASIL DAN PEMBAHASAN}

Hasil uji docking molekuler

Senyawa derivat phthalimide dengan nevirapine sebagai kontrol positif dan parasetamol sebagai kontrol negatif dioptimasi geometri untuk menghasilkan konformasi dengan energi terendah, yang menunjukkan kestabilan terbaik suatu struktur kimia.

Informasi makromolekul target dapat dilihat pada (tabel 2). Metode penentuan struktur makromolekul yang dipilih adalah $x$-Ray difraction karena dapat diaplikasikan untuk struktur makromolekul yang besar (>100 KDa) dan lebih presisi.

Tabel 2 Informasi makromolekul dan ligan kristalografi (Ding 1995)

\begin{tabular}{cc}
\hline Parameter & HIV-1 \\
\hline PDB ID & $1 \mathrm{HNV}$ \\
Organisme & Escherichia coli \\
Metode & $X$-Ray Difraction \\
Resolusi & $3.0 \AA$ \\
Ligan & TIBO \\
\hline
\end{tabular}

Ligan dan molekul air dihilangkan dari struktur makromolekul target karena dapat mengganggu proses docking. Namun apabila ada interaksi ikatan hidrogen dengan jembatan air maka eliminasi residu air tidak dapat dihilangkan. Pada dasarnya molekul air akan memediasi interaksi ligan dengan reseptor, sehingga hasil docking yang didapat semakin baik.
Tetapi proses docking akan berlangsung lebih kompleks karena variabel persamaan matematika docking yang perlu diselesaikan menjadi lebih banyak yang menyebabkan waktu docking semakin lama. Dengan begitu, perlu adanya optimasi antara akurasi dan kecepatan, di mana jika ingin prosesnya berjalan lebih cepat, maka akurasinya diturunkan hingga $70 \%$ sudah cukup mewakili hasil docking yang didapat. Begitu juga dengan adanya ligan yang terikat pada sisi aktif makromolekul akan menghalangi interaksi ligan yang akan ditambatkan.

Makromolekul yang telah disimpan dilakukan uji pendahuluan dan validasi metode menggunakan aplikasi PyRx. Makromolekul diatur sedemikian rupa dengan menentukan gridbox. Pengaturan gridbox untuk menentukan ruang berikatan ligan yang akan didocking. Ruang berikatan ligan ditentukan dengan merujuk kepada ligan yang sudah berikatan dengan makromolekul pada saat diunduh. Pengaturan pada gridbox meliputi center_x, center_y, center_z, untuk mengatur letak parameter box pada makromolekul, kemudian size_ $x$, size_ $y$, size_z, untuk menentukan besar kecilnya gridbox untuk ruang berikatan ligan tersebut (gambar 1).

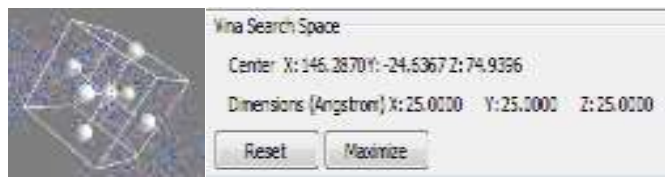

Gambar 1 Contoh pengaturan gridbox

RMSD merupakan nilai yang digunakan untuk menentukan apakah prediksi modus ikatan tersebut berhasil 
dan penting untuk validasi program docking.

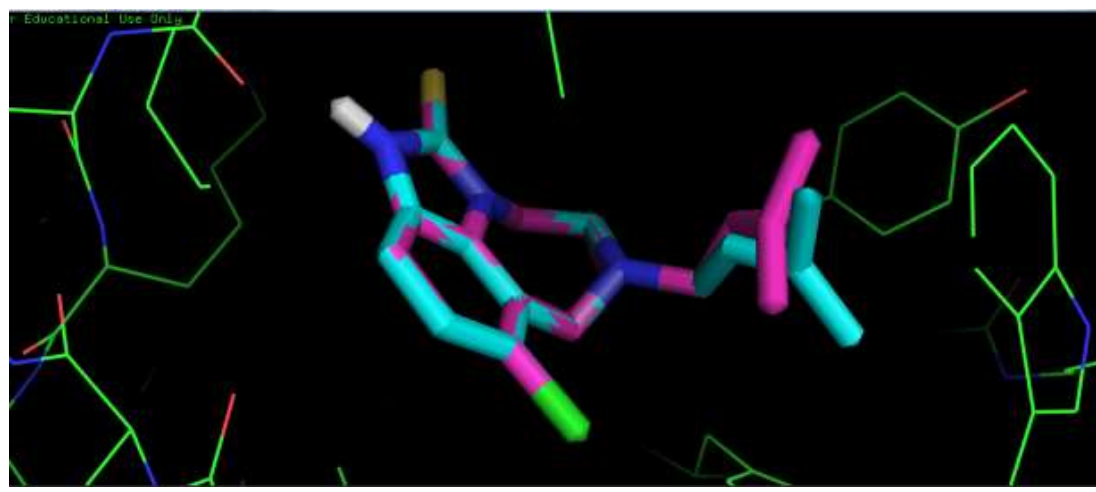

Gambar 2 Hasil validasi metode docking dengan Pymol

Nilai RMSD dikatakan baik jika $\leq$ $2 \AA$. Dengan penyimpangan yang semakin besar, semakin besar kesalahan pada prediksi interaksi ligan dengan makromolekul. Dari pengujian menggunakan software PyRx 0.8 , nilai RMSD dan $\Delta G_{\text {bind }}$ terbaik berada diposisi pertama.

Validasi Metode docking terhadap ligan natif dilakukan untuk mencari konformasi 3D ligan natif terhadap reseptor dengan memperhatikan koordinat pusat masa struktur dan besaran gridbox dari binding site pocket dalam satuan angstrom (Vina) atau number of points (AutoDock). Konformasi hasil docking yang diperoleh disejajarkan dengan konformasi ligan natif hasil pengukuran kristalografi yang dinyatakan dalam nilai Root Mean Square Deviation (RMSD). Nilai RMSD untuk kesejajaran konformasi struktur yang masih dapat diterima adalah kurang dari 3 namun yang paling optimal adalah kurang dari 2, semakin mendekati nilai 0 maka nilai kesejajaran semakin baik. Hasil perhitungan RMSD antara ligan asli dan hasil docking menunjukan nilai 0.000 yang menunjukan bahwa metode yang digunakan dapat digunakan untuk pengujian docking molekuler.

Nilai RMSD terbaik adalah nilai yang mendekati 0 . Sehingga konformasi pertama pada masing-masing ligan membandingkan nilai konformasi dengan dirinya sendiri sebagai konformasi terbaik. Selain melihat nilai $\Delta G_{\text {bind }}$ yang semakin kecil, interaksi dengan senyawa pembanding juga perlu diperhatikan karena interaksi dengan residu yang dikehendaki akan berpengaruh terhadap peran senyawa sebagai inhibitor.

Setelah semua proses pengoptimasian makromolekul selesai, maka file ini disimpan dalam format.pdbqt. Format ini berarti bahwa file pdb tersebut sudah diberikan muatan gasteiger untuk menyesuaikan dengan lingkungan docking sehingga dapat dilakukan perhitungan dengan benar.

Data hasil proses docking molekuler ligan uji terhadap HIV-1 reverse transcriptase menunjukan dari 35 ligan yang diuji, terdiri dari 33 ligan uji dan 2 ligan pembanding akan 
menghasilkan ligan yang diperingkatkan berdasarkan nilai $\Delta G_{\text {bind }}$ terbaik (terendah).

\begin{tabular}{ccc}
$\begin{array}{l}\text { Tabel 3 } \\
\text { phthalimide }\end{array}$ & $\begin{array}{c}\text { Hasil docking } \\
\text { terbaik dengan }\end{array}$ & $\begin{array}{c}\text { derivat } \\
\text { reverse transcriptase }\end{array}$ \\
\hline Ligan & $\begin{array}{c}\text { Nilai } \\
\text { HG bind } \\
\text { (kkal/mol) }\end{array}$ & $\begin{array}{c}\text { Nilai } \\
\text { Pengham } \\
\text { batan (\%) }\end{array}$ \\
\hline Senyawa 1 & $-9,8$ & 43 \\
\hline Senyawa 2 & $-9,2$ & 37 \\
\hline Senyawa 3 & $-9,5$ & 22 \\
\hline Senyawa 4 & $-8,8$ & 3 \\
\hline Senyawa 5 & $-8,3$ & 29 \\
\hline Senyawa 6 & $-8,7$ & 21 \\
\hline Senyawa 7 & $-8,3$ & 14 \\
\hline Senyawa 8 & $-8,9$ & 8 \\
\hline Senyawa 9 & $-8,8$ & 43 \\
\hline Senyawa 10 & $-9,3$ & 11 \\
\hline Senyawa 11 & $-9,1$ & 24 \\
\hline Senyawa 12 & $-8,7$ & 3 \\
\hline Senyawa 13 & $-8,6$ & 26 \\
\hline Senyawa 14 & $-9,4$ & 6 \\
\hline
\end{tabular}

\begin{tabular}{|ccc}
\hline Senyawa 15 & $-8,9$ & 20 \\
\hline Senyawa 16 & $-9,2$ & 52 \\
\hline Senyawa 17 & $-8,4$ & 16 \\
\hline Senyawa 18 & $-8,9$ & 32 \\
\hline Senyawa 19 & $-7,9$ & 84 \\
\hline Senyawa 20 & $-8,3$ & 61 \\
\hline Senyawa 21 & $-8,8$ & 43 \\
\hline Senyawa 22 & $-8,8$ & 43 \\
\hline Senyawa 23 & $-8,9$ & 37 \\
\hline Senyawa 24 & $-8,6$ & 22 \\
\hline Senyawa 25 & $-8,5$ & 3 \\
\hline Senyawa 26 & $-8,9$ & 29 \\
\hline Senyawa 27 & $-8,1$ & 21 \\
\hline Senyawa 28 & $-8,9$ & 8 \\
\hline Senyawa 29 & $-8,9$ & 43 \\
\hline Senyawa 30 & $-9,0$ & 11 \\
\hline Senyawa 31 & $-9,0$ & 24 \\
\hline Senyawa 32 & $-8,3$ & 3 \\
\hline Senyawa 33 & $-7,9$ & 26 \\
\hline
\end{tabular}
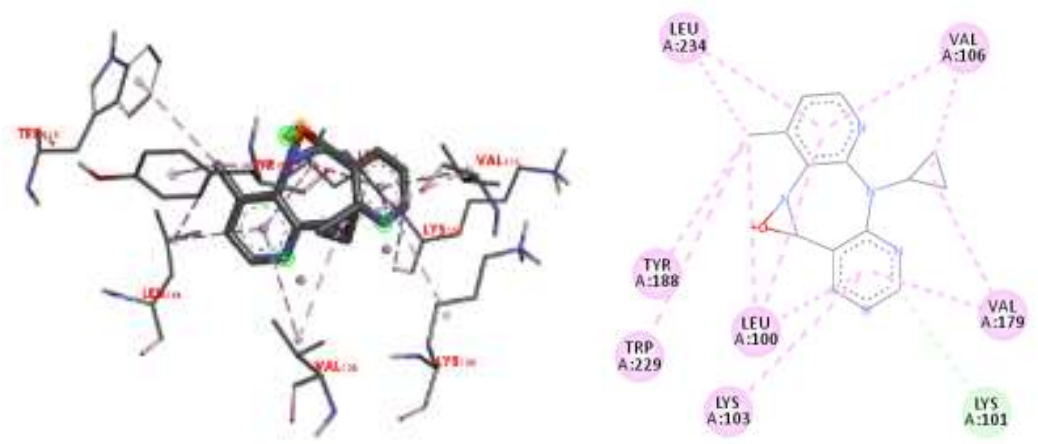

Interactions

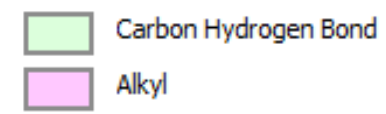

Pi-Alkyl

Gambar 3 Interaksi nevirapine dengan HIV-1 reverse transcriptase. 
Dari 33 konformasi tersebut, maka dipilihlah peringkat teratas yang memiliki nilai $\Delta G_{\text {bind }}$ terendah. Dari data hasil docking diperoleh nilai energi ikatan dengan rentang $-7,9 \mathrm{kkal} / \mathrm{mol}$ sampai $-9,8 \mathrm{kkal} / \mathrm{mol}$. Ligan dengan nilai terbaik kemudian dilihat interaksinya. Hasil yang bila dibandingkan dengan nevirapine sebagai pembanding positif memiliki kemampuan yang lebih potensial. Hal ini dilihat pada nilai energi ikatan yang lebih tinggi daripada kontrol positif.

Tabel 4 Interaksi derivat phthalimide dengan HIV-1 reverse transcriptase

\begin{tabular}{|c|c|c|c|c|c|}
\hline \multirow[b]{2}{*}{ Ligan } & \multirow{2}{*}{$\begin{array}{c}\Delta \mathrm{Gbind} \\
(\mathrm{kkal} / \mathrm{mol})\end{array}$} & \multicolumn{4}{|c|}{ Residu asam amino yang terlibat berdasarkan model interaksi } \\
\hline & & $\begin{array}{l}\text { Ikatan } \\
\text { Hidrogen }\end{array}$ & $\begin{array}{l}\text { Ikatan Van } \\
\text { der waals }\end{array}$ & Interaksi $\pi-\pi$ & $\begin{array}{l}\text { Interaksi } \\
\text { Hidrofobik }\end{array}$ \\
\hline Senyawa 1 & $-10,0$ & - & $\begin{array}{l}\text { His } 235 \\
\text { Lys101, } \\
\text { Lys102 }\end{array}$ & $\begin{array}{l}\text { Lys103, Pro236, Tyr318, } \\
\text { Val106, Leu234, Tyr181, } \\
\text { Trp229, Pro95, Leu100, } \\
\text { Tyr188 }\end{array}$ & Val179 \\
\hline Senyawa 2 & $-9,2$ & - & - & $\begin{array}{c}\text { Tyr318, Lys103, } \\
\text { Val106, Leu100, } \\
\text { Tyr181, Pro95, Trp229 }\end{array}$ & $\begin{array}{l}\text { Tyr188, } \\
\text { Val106, } \\
\text { Val179, } \\
\text { Tyr181 }\end{array}$ \\
\hline Senyawa 3 & $-9,6$ & Lys103 & - & $\begin{array}{c}\text { Val106, Tyr188, Leu100, } \\
\text { Tyr181, Trp229, Pro95, } \\
\text { Lys103 }\end{array}$ & $\begin{array}{l}\text { Phe227, } \\
\text { Val179, } \\
\text { Leu234 }\end{array}$ \\
\hline Senyawa 4 & $-8,8$ & $\begin{array}{l}\text { Lys } 101 \\
\text { Pro236 }\end{array}$ & - & $\begin{array}{l}\text { Val106, Tyr318, Leu234, } \\
\text { Pro95, Leu100, Tyr181 }\end{array}$ & $\begin{array}{l}\text { Tyr188, } \\
\text { Trp229, } \\
\text { Leu234 }\end{array}$ \\
\hline Senyawa 5 & $-8,4$ & Gly99 & - & $\begin{array}{l}\text { Val179, Leu100, } \\
\text { Phe227, Tyr188, } \\
\text { Leu234, Val106 }\end{array}$ & $\begin{array}{l}\text { Leu100, } \\
\text { Tyr181, } \\
\text { Val106 }\end{array}$ \\
\hline Senyawa 6 & $-8,9$ & Lys101 & - & $\begin{array}{c}\text { Lys103, Val179, Tyr188, } \\
\text { Pro95, Trp229, Tyr181, } \\
\text { Leu100 }\end{array}$ & $\begin{array}{l}\text { Val179, } \\
\text { Tyr181, } \\
\text { Tyr188, } \\
\text { Leu234, } \\
\text { Phe227 }\end{array}$ \\
\hline Senyawa 7 & $-8,3$ & Lys101 & - & $\begin{array}{l}\text { Tyr188, Val106, Tyr181, } \\
\text { Val179, Leu100, Leu234 }\end{array}$ & $\begin{array}{c}\text { Tyr181, } \\
\text { Pro95, Leu100 }\end{array}$ \\
\hline Senyawa 8 & $-9,0$ & His235 & - & $\begin{array}{l}\text { Val179, Lys103, Tyr188, } \\
\text { Tyr181, Trp229, Leu100 }\end{array}$ & $\begin{array}{c}\text { Tyr188, } \\
\text { Leu100, } \\
\text { Tyr181, Pro95 }\end{array}$ \\
\hline
\end{tabular}

Senyawa $9 \quad-2,4$

\begin{tabular}{|c|c|c|c|c|}
\hline Senyawa 10 & $-9,3$ & Lys101 & $\begin{array}{c}\text { Lys103, Val106, Tyr188, } \\
\text { Leu100, Tyr181, Trp229, } \\
\text { Pro95 }\end{array}$ & $\begin{array}{l}\text { Tyr188, } \\
\text { Leu234, } \\
\text { Val179 }\end{array}$ \\
\hline Senyawa 11 & $-9,1$ & - & $\begin{array}{l}\text { Lys101, Leu100, } \\
\text { Leu234, Val179 }\end{array}$ & $\begin{array}{c}\text { Val179, } \\
\text { Lys103, } \\
\text { Val106, } \\
\text { Tyr181 }\end{array}$ \\
\hline
\end{tabular}




\begin{tabular}{|c|c|c|c|c|c|}
\hline Senyawa 12 & $-8,7$ & - & - & $\begin{array}{l}\text { Trp229, Leu100, Val179, } \\
\text { Lys101 }\end{array}$ & $\begin{array}{l}\text { Leu100, } \\
\text { Tyr181, } \\
\text { Val179, } \\
\text { Lys103 }\end{array}$ \\
\hline Senyawa 13 & $-8,8$ & - & - & $\begin{array}{l}\text { Leu100, Tyr181, Pro95, } \\
\text { Leu234, Val106 }\end{array}$ & $\begin{array}{c}\text { Leu100, } \\
\text { Tyr181, } \\
\text { Pro95, Val179 }\end{array}$ \\
\hline Senyawa 14 & $-9,3$ & - & - & Leu100, Lys101, Val179 & $\begin{array}{l}\text { Lys103, } \\
\text { Leu100, } \\
\text { Tyr181, } \\
\text { Val179 }\end{array}$ \\
\hline Senyawa 15 & $-8,9$ & - & - & Val106, Val179, Leu100 & $\begin{array}{l}\text { Val179, } \\
\text { Lys103, } \\
\text { Lys101, } \\
\text { Leu100 }\end{array}$ \\
\hline Senyawa 16 & $-9,3$ & - & - & $\begin{array}{c}\text { Tyr188, Leu234, Tyr181, } \\
\text { Pro95, Leu100, Val106, } \\
\text { Tyr188 }\end{array}$ & $\begin{array}{l}\text { Lys103, } \\
\text { Leu100, } \\
\text { Leu234, } \\
\text { Tyr188, } \\
\text { Leu100, } \\
\text { Val106, } \\
\text { Tyr188 }\end{array}$ \\
\hline Senyawa 17 & $-8,4$ & Lys101 & - & $\begin{array}{l}\text { Val179, Leu100, Val106, } \\
\text { Leu234, Phe227, Tyr188 }\end{array}$ & $\begin{array}{l}\text { Val179, } \\
\text { Val106, } \\
\text { Leu100, } \\
\text { Tyr318, } \\
\text { Tyr181 }\end{array}$ \\
\hline Senyawa 18 & $-8,9$ & Lys101 & - & $\begin{array}{c}\text { Tyr181, Pro95, Trp229, } \\
\text { Tyr188, Leu100, Val106, } \\
\text { Lys103, Tyr318 }\end{array}$ & $\begin{array}{l}\text { Leu234, } \\
\text { Phe227, } \\
\text { Tyr188, } \\
\text { Val179 }\end{array}$ \\
\hline Senyawa 19 & $-7,9$ & - & - & $\begin{array}{c}\text { Lys103, Val179, } \\
\text { Leu100, Tyr188, Trp229, } \\
\text { Tyr181, Leu234 }\end{array}$ & $\begin{array}{l}\text { Leu100, } \\
\text { Leu234 }\end{array}$ \\
\hline Senyawa 20 & $-8,4$ & - & - & $\begin{array}{l}\text { Val106, Tyr181, Pro95, } \\
\text { Trp229, Tyr188, Leu100, } \\
\text { Tyr318, Lys103 }\end{array}$ & $\begin{array}{l}\text { Val106, } \\
\text { Tyr188, } \\
\text { Tyr181, } \\
\text { Val179 }\end{array}$ \\
\hline Senyawa 21 & $-8,9$ & - & - & $\begin{array}{l}\text { Tyr181, Tyr188, Trp229, } \\
\text { Leu100, Lys103, Val179 }\end{array}$ & $\begin{array}{l}\text { Tyr188, } \\
\text { Val106, } \\
\text { Phe227, } \\
\text { Val179 }\end{array}$ \\
\hline Senyawa 22 & $-8,9$ & $\begin{array}{l}\text { Lys103, } \\
\text { Lys101 }\end{array}$ & - & $\begin{array}{c}\text { Val106, Lys103, Tyr181, } \\
\text { Pro95, Trp229, Tyr188 }\end{array}$ & $\begin{array}{l}\text { Val179, } \\
\text { Tyr181, } \\
\text { Leu234 }\end{array}$ \\
\hline Senyawa 23 & $-8,9$ & - & - & $\begin{array}{l}\text { Lys101, Leu100, } \\
\text { Lys103, Val179 }\end{array}$ & $\begin{array}{l}\text { Lys 103, } \\
\text { Val179, } \\
\text { Tyr181, } \\
\text { Leu100 }\end{array}$ \\
\hline Senyawa 24 & $-8,6$ & - & - & $\begin{array}{l}\text { Val179, Leu100, } \\
\text { Phe227, Tyr188, } \\
\text { Leu234, Val106 }\end{array}$ & $\begin{array}{l}\text { Leu100, } \\
\text { Tyr181, } \\
\text { Val106 }\end{array}$ \\
\hline Senyawa 25 & $-8,5$ & - & - & $\begin{array}{l}\text { Tyr181, Pro95, Trp229, } \\
\text { Tyr188, Leu100, } \\
\text { Lys103, Val106, Tyr318 }\end{array}$ & $\begin{array}{l}\text { Tyr188, } \\
\text { Phe227, } \\
\text { Leu234, } \\
\text { Val179 }\end{array}$ \\
\hline Senyawa 26 & $-8,9$ & - & - & $\begin{array}{l}\text { Lys103, Tyr318, Val106, } \\
\text { Leu100, Leu234, } \\
\text { Trp229, Tyr188 }\end{array}$ & $\begin{array}{c}\text { Val106, } \\
\text { Phe227, } \\
\text { Leu234, } \\
\text { Val179 }\end{array}$ \\
\hline
\end{tabular}




\begin{tabular}{|c|c|c|c|c|c|}
\hline Senyawa 27 & $-8,2$ & $\begin{array}{l}\text { His235, } \\
\text { Tyr318 }\end{array}$ & - & $\begin{array}{c}\text { Leu100, Tyr181, } \\
\text { Leu234, Phe227, Val106 }\end{array}$ & $\begin{array}{c}\text { Lys 103, } \\
\text { Leu100, } \\
\text { Leu234, } \\
\text { Tyr188 }\end{array}$ \\
\hline Senyawa 28 & $-8,9$ & $\begin{array}{l}\text { Tyr318, } \\
\text { His235 }\end{array}$ & - & $\begin{array}{l}\text { Tyr181, Pro95, Trp229, } \\
\text { Leu100, Tyr188, } \\
\text { Lys103, Val106 }\end{array}$ & $\begin{array}{l}\text { Tyr188, } \\
\text { Leu234, } \\
\text { Val179 }\end{array}$ \\
\hline Senyawa 29 & $-8,9$ & His235 & - & $\begin{array}{c}\text { Pro95, Tyr181, Trp229, } \\
\text { Leu100, Tyr188 }\end{array}$ & $\begin{array}{c}\text { Tyr188, } \\
\text { Phe227, } \\
\text { Leu234, } \\
\text { Val179 }\end{array}$ \\
\hline Senyawa 30 & $-9,0$ & - & - & $\begin{array}{l}\text { Tyr181, Trp229, Pro95, } \\
\text { Leu100, Tyr188, } \\
\text { Lys103, Val179 }\end{array}$ & $\begin{array}{l}\text { Phe227, } \\
\text { Leu234, } \\
\text { Val179 }\end{array}$ \\
\hline Senyawa 31 & $-9,0$ & - & - & $\begin{array}{c}\text { Trp229, Pro95, Tyr188, } \\
\text { Leu100 }\end{array}$ & $\begin{array}{c}\text { Val106, } \\
\text { Tyr188, } \\
\text { Tyr181, } \\
\text { Leu100, } \\
\text { Val179 }\end{array}$ \\
\hline Senyawa 32 & $-8,3$ & - & - & $\begin{array}{c}\text { Tyr188, Leu100, } \\
\text { Phe227, Leu234, Val106 }\end{array}$ & $\begin{array}{c}\text { Tyr181,Leu10 } \\
\text { 0, Val106 }\end{array}$ \\
\hline Senyawa 33 & $-7,9$ & $\begin{array}{l}\text { His235, } \\
\text { Lys101 }\end{array}$ & - & $\begin{array}{c}\text { Val106, Tyr318, Lys103, } \\
\text { Leu100, Tyr188, Trp229, } \\
\text { Tyr181, Pro95 }\end{array}$ & $\begin{array}{l}\text { Leu234, } \\
\text { Tyr181, } \\
\text { Tyr188 }\end{array}$ \\
\hline
\end{tabular}

Ini menunjukkan bahwa derivat phthalimide memiliki potensi sebagai penghambat HIV-1 reverse transcriptase. Hasil docking kemudian disimpan dalam format.pdb dan dilihat interaksinya dengan software Discovery Studio Visualizer.

\section{KESIMPULAN}

Senyawa derivat phthalimide memiliki pola interaksi dengan residu asam amino yang sama dengan senyawa TIBO $R \quad 86183$ yang merupakan ligan asli makromolekul target HIV-1 reverse transcriptase.

\section{DAFTAR PUSTAKA}

Ding J. 1995. Structure of HIV-1 RT/TIBO $R 86183$ Complex Reveals Similarity in the Binding of Diverse Nonnucleoside Inhibitors. Structural biology. Vol.
2 , number 5 , may 1995 . Pp 407 415.

Enggar Saputri, Karisma \& Fakhmi, Nurul \& Kusumaningtyas, Erwinda \& Priyatama, Dedy \& Santoso, Broto. 2016. Docking Molekular Potensi Anti Diabetes Melitus Tipe 2 Turunan Zerumbon sebagai Inhibitor Aldosa Reduktase dengan Autodock-Vina. Chimica et Natura Acta Vol 4(1): 16-20.

Samee W, Ungwitayatorn J, Matayatsuk C, Pimthon J. 2004. 3D-QSAR Studies on Phthalimide Derivatives as HIV-1 Reverse transcriptase Inhibitors. ScienceAsia 30 (2004): 81-88. 
Talele TT, Khedkar SA and Rigby AC. 2010. Successful applications of computer aided drug discovery: moving drugs from concept to the clinic. Current topics in medicinal chemistry. 10(1) : 127-41

Valerie A. Braz, Mary D. Barkley, Rebecca A. Jockusch, and Patrick L. Wintrode. 2010. Binding of the Nonnucleoside Reverse Transcriptase Inhibitor Efavirenz to HIV-1 Reverse Transcriptase Monomers and Dimers. PMC Biochemistry. 49(49). 10565-10573. 